\title{
Effect of Teacher Performance Evaluation on School Effectiveness
}

* Dr. Muhammad Akram, Associate Professor (Corresponding Author)

** Dr. Farrukh Munir, Lecturer

*** Dr. Ahmad Bilal, Assistant Professor

\begin{abstract}
This study was conducted to measure the effect of teacher performance evaluation on school effectiveness in public high schools in Pakistan. Teacher evaluation is a formal and systematic process of evaluating teacher performance that plays an important role in enhancing school effectiveness. School effectiveness is a process that ensures that a particular school has effectively maintained a safe and orderly environment, implemented an instructional framework and curriculum that focuses on enhancing student learning, where the school monitoring system is highly responding, and where a competency-based system is in practice that ensures increased student achievement. A correlational research design was used to conduct this study. Using multistage sampling techniques, data were collected from 580 secondary school teachers in district Okara. Self-Assessment Instrument for Teacher Evaluation $(\alpha=.88)$ and School Effectiveness Questionnaire $((\alpha=.86)$ were used for data collection. The Pearson correlation coefficient showed that teacher evaluation scores and school effectiveness were significantly correlated with each other $(r=.69)$. As teacher performance evaluation scores increased, the score on school effectiveness also increased. Multiple linear regression analysis revealed that teacher performance evaluation score significantly predicted $46 \%$ of variance in school effectiveness. Further, female teachers were better on teacher performance evaluation score and school effectiveness. Teachers in urban schools showed higher scores on teacher performance evaluation scores and school effectiveness as compared to rural school teachers. Keywords: Teacher Performance Evaluation; Communication, School Effectiveness; Safe and Orderly Environment, Monitoring Student Progress
\end{abstract} Introduction

Teacher evaluation is a formal process of measuring teacher performance. Effective teachers meet the teacher quality standards, demonstrate a strong command of subject matter knowledge, implement different teaching strategies and improve students' learning, and exercise different assessment strategies that help them get feedback about their teaching (Akram, 2019; Akram \& Zepeda, 2015). Effective teachers contribute to developing a classroom environment that is conducive to learning, implement curriculum successfully, and monitor student progress that is highly required and commendable. Sanders and Rivers (1997) stated that an effective teacher can make a considerable difference in student achievement as compared to a less effective teacher. A plethora of research provides evidence that an effective teacher is the most important individual that can make a considerable contribution to student learning and achievement (Akram, 2019; Brophy, 1986; DarlingHammond, 2016; Hattie, 2012; Marzano \& Toth, 2013; Stronge \& Tucker, 2003; Tucker \& Stronge, 2005).

Historically, teachers have been evaluated through different tools such as classroom observation, portfolios, head teachers' ratings, students' ratings, and self-assessment (Akram, 2019). The use of any teacher evaluation instrument has its repercussions that are linked either to formative assessment purposes such as teacher professional development and improvement or summative assessment decisions such as promotion and incentives etc. Teacher self-assessment is one of the strongest tools used for teacher improvement purposes. (Akram \& Zepeda, 2015, 2013). Self-

* Institute of Education and Research, University of the Punjab, Lahore, Pakistan Email: akram.ier@pu.edu.pk

** Institute of Education and Research, University of the Punjab, Lahore, Pakistan Email: farrukh.ier@pu.edu.pk

*** Institute of Education and Research, University of the Punjab, Lahore, Pakistan Email: drahmadbilal.ier@pu.edu.pk 
assessment is a cost-effective and efficient method of teacher evaluation where teachers evaluate their performance on their own and, based on the evaluation, demonstrate the need for improvement. Selfassessment provides teachers an opportunity to judge their performance, and perform better when they are evaluated for summative purposes. Due to these benefits, the researchers will use teacher selfassessment tools for measuring teacher evaluation.

Teacher evaluation, when considered in a larger context, is assumed to contribute to school effectiveness. School effectiveness is a complex variable. Majority of the research on measuring school effectiveness focus on monitoring implementation guidelines for some school development plans (Goe, Bell, \& Little, 2008; Jacobson, Day, Leithwood, Johnson, Ylimaki, \& Giles, 2005). School effectiveness, therefore, is measured in terms of whether a particular school has successfully implemented the school development plans. Theorists and researchers have proposed various theories and models of school effectiveness that describe school development. More refined models of school effectiveness have been developed by Scheerens and Creemers, (1989), Scheerens and Stoel (1988) Ellett and Walberg (1979).

One of the latest models of School Effectiveness has been presented by Marzano (2012). Marzano stated that effective schools focus on developing a safe and orderly environment that ensures student success. Such schools implement curriculum that focuses on enhancing student learning. Effective schools strive for monitoring and reporting student progress as well as focus on developing a competency-based system to ensure student content mastery. This model of school effectiveness has theoretical and practical underpinning and successful evidences of school success. The researchers will use Marzano's model of school effectiveness. The literature on measuring the effect of teacher evaluation score on school effectiveness is absent in literature, especially in Pakistan. This study is an endeavor to fill this gap.

\section{Research Questions}

This study involved the following research questions:

1. What are teachers' perceptions about teacher performance evaluation and school effectiveness?

2. Is there a significant relationship between teacher evaluation scores and school effectiveness?

3. Do teacher evaluation scores affect school effectiveness?

4. Do male and female teachers perceive teacher evaluation and school effectiveness differently?

5. Do rural and urban teachers perceive teacher evaluation and school effectiveness differently?

\section{Conceptual Framework of the study}

The conceptual framework is a set of interconnected concepts that represent overall relationships among variables. This study is based on the teacher evaluation models of Danielson (1996), the work of Stronge (2010), and the teacher evaluation model of Akram and Zepeda (2015). For measuring school effectiveness, a model of Marzano (2012) has been used. The indicators of teacher evaluation and school effectiveness constructs have been given below.

\begin{tabular}{|c|c|}
\hline $\begin{array}{l}\text { Teacher Performance Evaluation } \\
\text { - Subject Matter Knowledge } \\
\text { - Instructional Planning and Strategies } \\
\text { - Assessment } \\
\text { - Classroom Learning Environment } \\
\text { - Effective Communication }\end{array}$ & $\begin{array}{l}\text { School Effectiveness } \\
\text { - Safe and orderly environment } \\
\text { - Viable Curriculum Focused on Enhancing } \\
\text { Student Learning } \\
\text { - Monitoring and reporting student progress } \\
\text { - A competency-based system to ensures } \\
\text { student content mastery }\end{array}$ \\
\hline
\end{tabular}

\section{Literature Review}

\section{Teacher Performance Evaluation}

Linking teacher evaluation score with school effectiveness is important. Teacher evaluation that leads to teacher effectiveness means the capability of a teacher to improve student performance and achieve certain goals (Akram \& Zepeda, 2015). Darling-Hammond (2000) stated that effective teachers share certain skills with their colleagues that help them grow professionally (Stronge \& Tucker, 2000). A plethora of research has evidenced that effective teachers perform certain roles with increased frequency that result in increased student achievement (Akram, 2019, 2018; Akram \& Zepeda, 2015). The focus then turns to the selection of indicators that have global understanding and representation to measure teacher quality. 
Various models of teacher evaluation have been historically used to measure teacher quality. Danielson's Framework for Teaching (1996), for example, is a model used in the US that helps identify the certain level of teacher quality. This model includes four domains such as planning and preparation, classroom environment, instruction, and professional responsibilities. Danielson used a rubric and rated teachers' teaching as unsatisfactory, basic, proficient, and distinguished based on their performance on these indicators. Other famous models of teacher evaluation used in the US include Bill and Gates' Measurement of Teaching (MET), and Marzano's (2000) Causal Teacher Evaluation Model.

Another example comes from Canada where education is a provincial entity and teacher evaluation is the responsibility of the States. Each state has its teacher evaluation system. In Ontario, for example, The Teacher Performance Appraisal System (TPAS) is exercised to improve student outcomes and reduce gaps in student achievement. According to the Ontario Ministry of Education (2008), TPAS includes New Teacher Induction Program (that involves teachers' support in mentoring, professional development in Literacy and Numeracy, Student Success, classroom management, communication skills, and instructional strategies) and Teacher Performance Appraisal for Experienced Teachers (TPAET) to support the growth and professional development of new teachers. Similar indicators of teacher quality are considered important while evaluating teachers in other states of Canada.

In Pakistan, a growing number of researchers are using National Professional Standards for Teachers designed by the Ministry of Education in 2009 to evaluate teacher performance (Akram \& Zepeda, 2015. Though these standards have not been implemented officially in public schools, their compatibility with internationally used teacher quality indicators has increased their practical significance. The standards include teachers' subject matter knowledge, instructional planning and strategies, assessment, classroom environment, effective communication, and others. Some of the researchers have employed these standards to measure teacher quality (Akram, 2019, 2018; Akram \& Zepeda, 2015, 2013). For this study, the researchers used the Teacher Evaluation Model of Akram and Zepeda (2015) which has previously been validated and used to measure teacher effectiveness.

\section{School Effectiveness}

Measuring school effectiveness has always been the focus of researchers and administrators. There is little consensus on the particular definition of this construct. Generally, school effectiveness is seen in the perspective of how effectively the organization is achieving school outcomes (Scheerens, 2013). Glasman and Biniaminov (1981) presented an input-output analysis model of schools and found that school inputs include school conditions and instructional personnel. They focused on taking school effectiveness in terms of how well the school conditions are suitable for learning and how well instructional personnel are prepared for effective teaching.

Murphy, Weil, Hallinger, and Mitman (1982) discussed a model of school effectiveness used in California which he named as "academic press". According to them, the academic press is a degree to which environmental forces press for student achievement on a school-wide basis. These concepts include various forces such as school policies, practices, expectations, norms, and rewards. Murphy, Hallinger, Weil, and Mitman (1983) studied school effectiveness and stated that school effectiveness includes three domains: instructional leadership, school leadership processes, and school leadership activities. Instructional leadership includes various factors such as framing school goals and activities, developing and promoting standards, protecting instructional time, and supervising and evaluating instruction. School leadership processes include various factors such as include communication, conflict resolution, decision making, and change processes. School leadership activities include behaviors, practices, and policies. Combining these, these authors presented a broad-based conceptual model of school effectiveness stating how schools as organizations function. Ellett and Walberg (1979) presented models of teacher effectiveness with focusing on organization-level factors such as successful curriculum implementation, implementation of policies, and leadership roles.

Marzano (2012) presented one of the latest models of school effectiveness. He stated that effective schools are those who deeply care for maintaining a safe and orderly environment of school, focus on Instructional framework and curriculum, and monitor and report student progress. A safe and orderly environment is one of the key factors of school effectiveness. Viable Curriculum Focused on Enhancing Student Learning is another factor that ensures that the school has a written curriculum that adequately addresses important 21 st-century skills. It also includes that teachers can describe the 
essential contents when asked, and all students have the opportunity to learn the critical content of the curriculum. Moreover, clear and measurable goals are established and focused on critical needs regarding improving overall student achievement at the school level.

Effective schools are also required to monitor and report student progress in an effective manner. Effective schools analyze, interpret, and use data to regularly monitor progress toward achieving goals for individual students. Effective schools ensure that written goals are available for each student in terms of their performance on local and external assessments so that stakeholders such as parents can effectively be communicated. Another important factor of school effectiveness includes a competency-based system that ensures student mastery. Student status and progress for each essential element in each subject area are continually monitored. The school schedule is designed to accommodate students moving at a pace appropriate to their backgrounds and needs.

\section{Linking Teacher Performance Evaluation and School effectiveness}

The researcher reviewed some studies that revealed that how teacher evaluation or teacher effectiveness is essential for student achievement, school performance, and school effectiveness. Ellett and Teddlie (2003) investigated and found that teacher evaluation affects the school effectiveness positively. Aziz (2010) examined that how teachers' competencies affect the student achievement in Pakistan and found teacher evaluation score was significantly correlated with student achievement, indicated that evaluation of teacher is essential to enhance the teachers' performance and student achievement or school effectiveness. The study suggested that teachers' performance should be measured based on these effective practices and suggested them training for their professional development. Another study was conducted by Siddiqui (2010) on teacher evaluation and also found a significant relationship between teacher effectiveness score and school effectiveness, indicated that teacher effectiveness is essential for school effectiveness. The study further recommended that headteachers should enhance the effectiveness of teachers through making their evaluations that might enhance student learning and school performance.

Darling-Hammond, Hyler, and Gardner (2017) examined some essential components of an evaluation system of teachers that affect their professional development and effectiveness. The study found that an effective teacher evaluation system improves teacher effectiveness that is essential for school performance. Akram and Zepeda (2015) developed and validated a teacher self-assessment instrument in their study by taking five teacher performance components: knowledge about subject matter, planning for instruction and strategies, learning environment, assessment, and effective communication. The data were gathered from teachers who self-evaluated their performance on the questionnaire. After ensuring the validity and reliability of the instrument, the study revealed a significant and positive relationship between teacher self-evaluation and student outcomes, indicated that the instrument is reliable and valid to evaluate the teachers.

Mathus (2017) examined the relationship between teacher evaluation scores and student outcomes and found that teachers' evaluation affects student achievement. The study suggested that by making performance-based teacher evaluations, school performance can be enhanced. DarlingHammond (2015) examined the quality of teacher and student achievement and found that teacher effectiveness affects student achievement positively. Quantitative analyses indicate that teacher quality strongly correlates with student achievement. The study suggested that by improving teacher quality and professional development through teacher evaluation, student achievement and school effectiveness can be improved. Oviawe (2016) also examined the effect of teacher's effectiveness on student outcomes and revealed that there was a positive relationship between them. The study recommended that teacher effectiveness can be enhanced through teacher professional development.

Akram (2019) examined the relationship between teacher effectiveness and student achievement. By adopting the multistage sampling technique, data were gathered from students with the help of a questionnaire. The study found a significant and positive relationship between teacher effectiveness scores and student achievement. Multiple regression analysis revealed $32 \%$ of the variance in student outcomes in English and 12\% of variance in student outcomes in mathematics was explained by teacher effectiveness score that indicated teacher effectiveness is essential for student achievement. Malik and Akram (2020) also examined the effect of teacher evaluation on school performance and found a moderate relationship between them. The study further also revealed that teacher evaluation affects school performance positively, indicated the importance of teacher evaluation for student achievement and school effectiveness. Studies provided evidence that 
evaluating teachers is essential to enhance teacher effectiveness, student learning, and school effectiveness.

\section{Methodology}

It was a survey research with a correlational design. Using the multistage sampling technique, 10 boys' and 10 girls' public high schools of District Okara were selected through a simple random sampling technique. At the second stage, all teachers in these 20 high schools were selected as a sample of the study. The overall sample included 580 teachers with $310(53 \%)$ male and $270(47 \%)$, female teachers.

\section{Instrumentation}

Two questionnaires were used for data collection. First: Akram and Zepeda (2015) developed a Selfassessment Instrument for Teacher Evaluation (SITE) that includes five factors. The scales of the questionnaire are as: Never (1), Rarely (2), Sometimes (3), Often (4), and Always (5). The scales meant that highly effective teachers would perhaps demonstrate always a certain level of performance that relates to higher teacher effectiveness and vice versa. The overall reliability of the SITE was 0.88 with factor-wise reliabilities as: Subject Matter Knowledge $(\alpha=.84)$, Instructional Planning and Strategies $(\alpha=.82)$, Assessment $(\alpha=.80)$, Classroom Learning Environment $(\alpha=.78)$, and Effective Communication $(\alpha=.78)$. Exploratory as well as confirmatory factor analyses revealed that the SITE presented a good model fit (Akram \& Zepeda, 2015).

Second, a five-point Likert scale named, School Effectiveness Questionnaire (SEQ) was developed by the researchers based on Marzano's model of school effectiveness (2012). Exploratory factor analysis revealed that the SEQ includes five factors. Factor-wise reliabilities were as: Safe and orderly environment $(\alpha=.78)$, Instructional framework $(\alpha=.82)$, Curriculum Focused on Enhancing Student Learning $(\alpha=.84)$, Student progress $(\alpha=.80)$, and (5) Competency-based system for students $(\alpha=.74)$ with overall reliability as high $(\alpha=.86)$.

\section{Data Collection}

The data were collected in personal visits to the participants. One of the researchers visited all the sampled schools and distributed both questionnaires to all available teachers in the schools. Proper consent from each participant was taken before questionnaires distribution. All ethical concerns such as confidentiality and data safety were given careful consideration. In total, 580 respondents completed the questionnaires.

\section{Data Analysis}

Firstly, descriptive statistics were calculated to measure teacher evaluation scores. Table 1 shows descriptive statistics with minimum and maximum values.

Table 1: Teacher Evaluation-Descriptive Statistics $(N=580)$

\begin{tabular}{lll}
\hline \multicolumn{1}{c}{ Indicators } & Mean & \multicolumn{1}{c}{$S D$} \\
\hline Subject Matter Knowledge & 32.33 & 4.655 \\
Instructional Planning and strategies & 20.16 & 4.275 \\
Assessment & 14.35 & 3.604 \\
Learning Environment & 20.14 & 3.808 \\
Effective Communication & 13.16 & 3.345 \\
Overall & 112.67 & 16.580 \\
\hline
\end{tabular}

According to the table, that the highest mean score was demonstrated on subject matte knowledge $(M=32.33$, S.D. $=4.655)$, followed by the instructional planning and strategies $(M=20.16$, S.D. $=4.275)$. The lowest mean score was found on effective communication (M=13.16, S.D. =3.345). Overall, factor-wise statistics show that teachers often performed their roles.

Table 2: School Effectiveness-Descriptive Statistics $(N=580)$

\begin{tabular}{|c|c|c|c|c|}
\hline Factor & Min & $\operatorname{Max}$ & Mean & $S D$ \\
\hline Safe and orderly Environment & 10.00 & 6500 & 23.714 & 4.765 \\
\hline $\begin{array}{l}\text { Curriculum Focused on enhancing } \\
\text { Learning }\end{array}$ & 10.00 & 72.00 & 27.567 & 6.765 \\
\hline $\begin{array}{l}\text { Monitoring and Reporting Student } \\
\text { Progress }\end{array}$ & 5.00 & 47.00 & 14.675 & 3.012 \\
\hline $\begin{array}{l}\text { Competency Based Student } \\
\text { Assessment System }\end{array}$ & 6.00 & 64.00 & 110.543 & 4.432 \\
\hline Overall & 47.00 & 195.00 & 110.543 & 18.322 \\
\hline
\end{tabular}


According to Table 2, the teachers perceived their schools were most focused on implementing curriculum to enhance learning $(M=28.567$, S.D. $=6.576)$, followed by developing a safe and orderly environment $(M=23.714$, S.D. $=4.765)$. The lowest mean score was shown in monitoring and reporting student performance $(\mathrm{M}=14.675$, S.D. $=3.012)$.

Table 3:

Relationship between Teacher Performance Evaluation and School Effectiveness

School Effectiveness ( $\mathrm{r}$ )

Teacher Evaluation .69

For measuring the relationship between teacher evaluation and school effectiveness, the Pearson correlation coefficient was computed. A strong positive correlation between teacher performance evaluation and school effectiveness was found $(r=.69)$.

Table 4:

Regression Analysis- Teacher Evaluation and School Effectiveness

\begin{tabular}{llllll}
\hline Model & Sum of Square & df & Mean Square & f & Sig. \\
\hline Regression & 42234.203 & 1 & 6127.423 & 94.947 & .000 \\
Residual & 67456.643 & 579 & 67.453 & & \\
Total & 96758.456 & 579 & & & \\
\hline
\end{tabular}

Multiple regression analysis was run to measure the effect of teacher evaluation score on school effectiveness. According to Table 4, teacher performance evaluation significantly predicted school effectiveness, $\mathrm{R}^{2}=.331, F(1,579)=94.947, p<.001$. The $\mathrm{R}^{2}$ value showed that the teacher evaluation score predicted 46 percent of variance in school effectiveness. The results showed that teacher evaluation as a single factor contributed significantly to predict school effectiveness.

Table 5:

Teacher Evaluation Comparison Based on their Gender

\begin{tabular}{llllllll}
\hline Factors & Gender & $\mathrm{N}$ & Mean & SD & $\mathrm{t}$ & $\mathrm{df}$ & Sig. \\
\hline \multirow{3}{*}{ Subject matter knowledge } & Male & 310 & 31.24 & 4.456 & 1.977 & 578 & .021 \\
& Female & 270 & 33.00 & 6.373 & & & \\
Instructional Planning & Male & 310 & 20.03 & 4.911 & -.294 & 578 & .002 \\
& Female & 270 & 22.18 & 5.750 & & & \\
Assessment & Male & 310 & 14.71 & 4.692 & 1.059 & 578 & .015 \\
Learning Environment & Female & 270 & 15.22 & 4.572 & & & \\
\multirow{4}{*}{ Effective Communication } & Male & 310 & 20.86 & 3.349 & 2.453 & 578 & .011 \\
& Female & 270 & 21.92 & 3.932 & & & \\
Overall & Male & 310 & 12.46 & 2.256 & 1.645 & 578 & .002 \\
& Female & 270 & 13.07 & 2.368 & & & \\
& Male & 310 & 125.03 & 17.391 & 2.012 & 578 & .000
\end{tabular}

The t-test for independent samples was used to compare teachers' perceptions of teacher evaluation. According to the results, a significant difference was found between male and female teachers perceptions of teacher evaluation. Female teachers rated themselves higher on all factors of teacher evaluation than male teachers with the overall significant model as $t(578)=2.012, \mathrm{p}>0.00$. Factor was and overall results can be seen in table 5.

Table 6:

Gender-Based Comparison-School Effectiveness

\begin{tabular}{|c|c|c|c|c|c|c|c|}
\hline Factor & Gender & $\mathrm{N}$ & $\mathrm{M}$ & SD & $\mathrm{t}$ & df & Sig. \\
\hline \multirow[b]{2}{*}{ Safe and orderly Environment } & Male & 310 & 22.88 & 4.661 & .193 & 578 & .001 \\
\hline & Female & 270 & 23.79 & 4.869 & & & \\
\hline \multirow{2}{*}{$\begin{array}{l}\text { Curriculum focused on enhancing } \\
\text { learning }\end{array}$} & Male & 310 & 28.23 & 7.951 & .482 & 578 & .002 \\
\hline & Female & 270 & 29.89 & 6.576 & & & \\
\hline \multirow{2}{*}{$\begin{array}{l}\text { Monitoring and Reporting student } \\
\text { progress }\end{array}$} & Male & 310 & 14.28 & 3.350 & 1.33 & 578 & .000 \\
\hline & Female & 270 & 15.77 & 3.756 & & & \\
\hline Competency-based system to ensure & Male & 310 & 17.53 & 4.176 & .524 & 578 & .003 \\
\hline
\end{tabular}




\begin{tabular}{llllllll}
\hline student content mastery & Female & 270 & 18.78 & 4.756 & & & \\
\multirow{2}{*}{ Overall } & Male & 310 & 109.90 & 18.273 & .075 & 578 & .000 \\
& Female & 270 & 113.04 & 18.190 & & &
\end{tabular}

T-test for independent samples was used to compare teachers' perceptions of school effectiveness. The study found significant differences in teachers perceptions on all factors with an overall difference as $t(578)=.075, \mathrm{p}>0.000$. Female teachers perceived their schools were more effective as compared to male schools. The detailed results are given in Table 6.

Table 7:

Location-Based Comparison-Teacher Evaluation

\begin{tabular}{|c|c|c|c|c|c|c|c|}
\hline Factors & Location & $\mathrm{N}$ & Mean & SD & $\mathrm{t}$ & $\mathrm{df}$ & Sig. \\
\hline \multirow[t]{2}{*}{ Subject matter knowledge } & Rural & 310 & 30.14 & 4.143 & 1.354 & 578 & .000 \\
\hline & Urban & 270 & 32.26 & 5.853 & & & \\
\hline \multirow[t]{2}{*}{ Instructional Planning } & Rural & 310 & 18.65 & 4.394 & 4.371 & 578 & .000 \\
\hline & Urban & 270 & 21.54 & 5.294 & & & \\
\hline \multirow{2}{*}{ Assessment } & Rural & 310 & 13.95 & 3.883 & 2.785 & 578 & .021 \\
\hline & Urban & 270 & 15.52 & 4.673 & & & \\
\hline \multirow[t]{2}{*}{ Learning Environment } & Rural & 310 & 22.19 & 3.152 & 2.197 & 578 & .004 \\
\hline & Urban & 270 & 21.02 & 3.867 & & & \\
\hline \multirow{2}{*}{ Effective Communication } & Rural & 310 & 14.71 & 1.825 & 2.053 & 578 & .041 \\
\hline & Urban & 270 & 15.05 & 2.494 & & & \\
\hline \multirow[t]{2}{*}{ Overall } & Rural & 310 & 110.14 & 13.675 & 2.390 & 578 & .001 \\
\hline & Urban & 270 & 119.05 & 18.776 & & & \\
\hline
\end{tabular}

T-test for independent samples was used to compare teachers' perceptions of teacher evaluation based on their school location i.e. rural or urban. Table 7 shows urban teachers evaluated their performance as more effective on all factors as compared to rural school teachers. Overall, urban teachers perceived they were more effective teachers as compared to rural school teachers with an overall significant difference as $t(578)=2.390, \mathrm{p}>0.000$.

Table 8:

Location-Based Comparison-School Effectiveness

\begin{tabular}{|c|c|c|c|c|c|c|c|}
\hline Factor & Location & $\mathrm{N}$ & Mean & S.D. & $\mathrm{t}$ & df & Sig. \\
\hline \multirow{2}{*}{ Safe and orderly Environment } & Rural & 210 & 21.85 & 4.992 & 3.454 & 578 & .002 \\
\hline & Urban & 390 & 24.13 & 4.635 & & & \\
\hline \multirow{2}{*}{$\begin{array}{l}\text { Curriculum focused on enhancing } \\
\text { learning }\end{array}$} & Rural & 210 & 24.13 & 6.840 & 5.095 & 578 & .000 \\
\hline & Urban & 390 & 28.63 & 6.743 & & & \\
\hline \multirow{2}{*}{$\begin{array}{l}\text { Monitoring and Reporting student } \\
\text { progress }\end{array}$} & Rural & 210 & 13.53 & 3.946 & 5.309 & 578 & .004 \\
\hline & Urban & 390 & 15.93 & 3.556 & & & \\
\hline \multirow{2}{*}{$\begin{array}{l}\text { Competency-based system to ensure } \\
\text { student content mastery }\end{array}$} & Rural & 210 & 17.05 & 5.964 & 3.286 & 578 & .002 \\
\hline & Urban & 390 & 17.94 & 4.278 & & & \\
\hline \multirow{2}{*}{ Overall } & Rural & 210 & 96.59 & 19.532 & 6.360 & 578 & .000 \\
\hline & Urban & 390 & 118.9 & 15.949 & & & \\
\hline
\end{tabular}

The t-test for independent samples was used to compare teachers perceptions of school effectiveness based on their school location. Table 8 shows that urban teachers perceived they had more effective schools as compared to the rural schools, $t(598)=6.360, \mathrm{p}=.000$. Factor-wise comparisons also showed that urban teachers perception they had a more safe and orderly environment, curriculum with more focused on enhancing learning, and better monitoring and reporting system of student progress. A summary of the results is given in Table 8.

\section{Findings}

The study found a positive significant relationship between teacher performance evaluation and school effectiveness. The study found that teacher performance evaluation scores significantly predicted school effectiveness. Significant differences between teachers' perception of teacher performance evaluation and school effectiveness were found. Female teachers perceived they were 
more effective than male teachers while urban teachers perceived they were better teachers as compared to rural teachers. Further, female teachers perceived their schools were more effective than male schools, while urban teachers perceived their schools were more effective than rural schools.

\section{Discussion}

The findings of this study lead to discuss important assertions. The significant relationship between teacher effectiveness and school effectiveness provides evidence that if the schools evaluate their teacher on the national professional standards for teacher evaluation, it might result in improve school effectiveness. Various previous studies find a similar relationship between teacher performance Evaluation score and school effectiveness indicators. Akram (2019; Akram \& Zepeda, 2015; DarlingHammond et al., 2017; Ellett \& Teddlie, 2003; Malik \& Akram, 2020; Marzano, 2012; Mathus, 2017; Oviawe; 2016; Siddiqui, 2010). The reasons for positive relationships between teacher performance evaluation score and school effectiveness include their causal attribution which is historically proven in the literature.

It is worth noting that the construct of teacher performance evaluation includes comprehensive teacher quality indicators endorsed by the Ministry of Education Pakistan under the national professional standards for teachers and have been exercised by teachers across the globe. It was expected that teachers would demonstrate higher performance on these indicators. Moreover, the indicators of school effectiveness have been emerging in more depth in the literature for a decade and are closely associated with teacher quality indicators.

Female teachers rated themselves as more effective teachers as compared to male teachers on teacher performance evaluation indicators. Female teachers perceived they were better in content matter knowledge, used more effectively the instructional strategies, and used more effective assessment as compared to male teachers. Female teachers also perceived they were better at creating a learning environment in the classroom and using communication skills. The findings of this study are compatible with other studies (Akram \& Zepeda, 2015, 2013).

\section{Recommendations}

1. Based on the finding of the significant effect of teacher performance evaluation on school effectiveness, it is recommended that teachers should focus on managing and improving their performance on the national professional standards for teachers so that schools may work more effectively.

2. Female teachers performed better on teacher performance evaluation standards as well as school effectiveness factors; male teachers, therefore, should be given training and motivated to perform better on teacher effectiveness standards and school effectiveness factors.

3. Urban school teachers performed better on teacher evaluation and school effectiveness; teachers in rural schools should be encouraged and motivated to perform better on teacher evaluation standards and teacher effectiveness factors.

4. Further studies may be conducted to know why rural teachers rated themselves at a lower level on teacher evaluation and school effectiveness indicators.

\section{References}

Akram, M. (2018). Development and validation of school teacher effectiveness questionnaire. Journal of Research \& Reflections in Education (JRRE), 12(2), 154-174.

Akram, M. (2019). Relationship between students' perceptions of teacher effectiveness and student achievement at secondary school level. Bulletin of Education and Research, 41(2), 93-108.

Akram, M., \& Zepeda, S. J. (2013). Correlating teacher self-assessment score with student achievement in English and mathematics. Pakistan Journal of Education, 30(2), 13-32.

Akram, M., \& Zepeda, S. J. (2015). Development and validation of a teacher self-assessment instrument. Journal of Research \& Reflections in Education, 9(2), 134-148.

Aziz, M. A. (2010). Effect of demographic factors and teacher' competencies on the achievement of secondary school students in the Punjab. (Doctoral dissertation), Allama Iqbal Open University, Islamabad.

Clauset Jr, K. H., \& Gaynor, A. K. (1982). A Systems Perspective on Effective schools. Educational Leadership, 40(3), 54-59.

Danielson, C. (1996). Enhancing professional practice: A framework for teaching. Alexandria, VA: Association for Supervision and Curriculum Development. 
$\overline{\text { Darling-Hammond, L. (2015). Getting teacher evaluation right: What matters for effectiveness and }}$ improvement? Teachers College Press.

Darling-Hammond, L., Hyler, M. E., \& Gardner, M. (2017). Effective teacher professional development. Learning Policy Institute.

Ellett, C. D., \& Teddlie, C. (2003). Teacher evaluation, teacher effectiveness and school effectiveness: Perspectives from the USA. Journal of Personnel Evaluation in Education, 17(1), 101-128.

Ellett, C. D., \& Walberg, H. J. (1979). Principals' competency, environment, and outcomes. Educational Environments and Effects, 140-164.

Glasman, N. S., \& Biniaminov, I. (1981). Input-output analyses of schools. Review of Educational Research, 51(4), 509-539.

Goe, L., Bell, C., \& Little, O. (2008). Approaches to Evaluating Teacher Effectiveness: A Research Synthesis. National Comprehensive Center for Teacher Quality.

Jacobson, S. L., Day, C., Leithwood, K., Johnson, L., Ylimaki, R., \& Giles, C. (2005). Successful leadership in challenging US schools: Enabling principles, enabling schools. Journal of Educational Administration.

Malik, M. I., \& Akram, M. (2020). Effect of head teacher's effectiveness on school performance at secondary school level. Journal of Educational Sciences, 7(1), 76-97.

Marzano, R. J. (2012). Marzano levels of school effectiveness. Marzano laboratories.

Marzano, R. J., \& Toth, M. D. (2013). Teacher evaluation that makes a difference: A new model for teacher growth and student achievement. ASCD.

Mathus, M. A. (2017). The relationship between teacher evaluation ratings and student achievement in a rural, Midwest school district. (Doctoral dissertation), Lindenwood University.

Murphy, J., Hallinger, P., \& Mitman, A. (1983). Problems with research on educational leadership: Issues to be addressed. Educational Evaluation and Policy Analysis, 5(3), 297-305.

Murphy, J. F., Weil, M., Hallinger, P., \& Mitman, A. (1982). Academic press: Translating high expectations into school policies and classroom practices. Educational Leadership, 40(3), 2226.

Oviawe, M. J. I. (2016). Teachers' effectiveness as correlates of students' academic achievement in basic technology in Nigeria. International Journal of Academic Research in Progressive Education and Development, 2(5), 111-119.

Sanders, W. L., Wright, S. P., \& Horn, S. P. (1997). Teacher and classroom context effects on student achievement: Implications for teacher evaluation. Journal of personnel evaluation in education, 11(1), 57-67.

Scheerens, J. (2013). The use of theory in school effectiveness research revisited. School effectiveness and school improvement, 24(1), 1-38.

Scheerens, J., \& Creemers, B. P. (1989). Conceptualizing school effectiveness. International journal of educational research, 13(7), 691-706.

Siddiqui, T. K. (2010). A study of teacher competencies and teaching practices for school effectiveness in workers welfare model schools. (Doctoral dissertation), Foundation University, College of Liberal Arts and Sciences, Rawalpindi.

Stronge, J. H. (2010). Evaluating what good teachers do: Eight research-based standards for assessing teacher excellence. Larchmont, NY: Eye on Education.

Stronge, J. H., \& Tucker, P. D. (2000). Teacher evaluation and student achievement. Student Assessment Series. NEA Professional Library, Distribution Center, PO Box 2035, Annapolis Junction, MD 20701-2035.

Stronge, J. H., \& Tucker, P. D. (2003). Handbook on teacher evaluation: Assessing and improving performance. Larchmont, NY: Eye on Education. 